Renata Hołda

ORCID: https://orcid.org/0000-0003-1019-2555

Uniwersytet Jagielloński

Instytut Studiów Międzykulturowych

\title{
Prawo do ogrodu. Ogrodnicy w przestrzeni miasta
}

\section{The right to a garden. Gardeners in urban space}

\author{
Fresh, free and beautiful
}

Obordo 2018)

\begin{abstract}
The aim of my article is to present the activities of urban gardeners - a decentralized, grassroots movement that implements various forms of plant cultivation in the city. It is an intersection of a hobby interest in the cultivation of flowers, vegetables and herbs with various forms of urban activism, as well as ecological trends and an interest in the protection of the Earth and in the rational use of its resources. I treat urban gardening as one of the urban movements, and its activities as a kind of infra-politics. However, I point out that it cannot be treated only in terms of resistance, but that its analyses should take into account the reaction of the adversaries; a reaction which takes over the signs of social insubordination and turns it to its own advantage.
\end{abstract}

Keywords: urban gardening, urban movements, resistance, urban anthropology

Celem mojego artykułu jest przedstawienie działalności miejskich ogrodników - zdecentralizowanego, oddolnego ruchu realizującego różne formy upraw roślinnych w mieście. Krzyżują się w nim hobbystyczne zainteresowania uprawą kwiatów, warzyw i ziól, różne formy aktywizmu miejskiego oraz tendencje ekologiczne, zainteresowania ochroną Ziemi i racjonalnym wykorzystaniem jej zasobów. Miejskie ogrodnictwo traktuję jako jeden z ruchów miejskich, a jego działania - jako rodzaj infrapolityki. Wskazuję jednak, że nie można go traktować wyłącznie w kategoriach oporu, lecz w jego analizach należy uwzględniać reakcję adwersarzy, która przejmuje znaki oporu i obraca na swą korzyść.

Słowa kluczowe: miejskie ogrodnictwo, urban gardening, ruchy miejskie, opór, antropologia miasta

Odebrano / Received: 24.04.2021

Zaakceptowano / Accepted: 05.10.2021 


\section{Wprowadzenie}

„Ogród” współcześnie kojarzy się zamkniętą i prywatną przestrzenią, zwykle z hodowlą kwiatów i innych roślin ozdobnych dobranych ze względu na ich oryginalność i walory estetyczne. Współczesne trendy miejskiego ogrodnictwa zmieniają to rozumienie, na nowo definiując, czym może być ogród, gdzie może się znajdować i czyją być własnością oraz w jaki sposób może być zagospodarowany. Jego zwolennicy dążą do harmonijnego połączenia przestrzeni miejskiej i architektury z zielenią, przy czym chodzi o coś więcej niż posadzenie pojedynczych drzew czy założenie trawników. Niektórzy ogrodnicy zresztą zdecydowanie odradzają zakładanie poletek strzyżonej trawy, wskazując, że jej utrzymanie w warunkach miejskich wymaga nie tylko nakładów pracy i stosowania zanieczyszczających powietrze maszyn, lecz wiąże się również z nadmiernym zużyciem wody, stosowaniem szkodliwych nawozów i pestycydów, a w efekcie - z marnowaniem zasobów i miejsca, które można wykorzystać w bardziej przydatny i przyjazny dla środowiska sposób (Flores 2006).

Zjawisko miejskiego ogrodnictwa, zdecentralizowanego ruchu miejskiego zajmującego się uprawą roślin w mieście lub w jego pobliżu, współcześnie przybiera na sile. Popularność zyskało w Stanach Zjednoczonych, na zachodzie Europy, coraz częściej pojawia się w Polsce. Krzyżują się w nim hobbystyczne zainteresowania uprawą kwiatów, warzyw i ziól, różne formy aktywizmu miejskiego oraz tendencje ekologiczne, zainteresowania ochroną Ziemi i racjonalnym wykorzystaniem jej zasobów.

Artykuł ma charakter przeglądowy i porządkujący, a nie empiryczny. Wykorzystuję w nim jednak - zwłaszcza w przypadku materiałów dotyczących Polski - również własne obserwacje oraz materiały z mediów społecznościowych udostępnianych przez zwolenników omawianego ruchu.

\section{Konieczne rozróżnienia}

Poza nazwą „urban gardening”, na określenie tego typu działalności pojawiają się także inne terminy, takie jak „urban farming” czy „urban agriculture”, które w języku polskim można określić odpowiednikiem „rolnictwo miejskie”. Związki między ogrodnictwem a rolnictwem miejskim są różnie definiowane. Jedni traktują rolnictwo jako szczególny typ miejskiej działalności ogrodniczej ukierunkowanej na uprawy użytkowe (Certomà 2015: 16; Prové, Kemper, Loudiyi 2018: 18), inni wskazują na nie, jako na bardziej ogólny termin. W tym ostatnim przypadku ujmowane jest szeroko jako:

wszystkie inicjatywy związane z produkcją żywności na obszarach miejskich i wokół nich. Oznacza to, że UA [urban agriculture - RH] obejmuje ogrody społecznościowe lub partyzanckie, istniejące profesjonalne gospodarstwa poszukujące połączeń z centrum miasta, a także bardziej innowacyjne formy UA, takie jak rolnictwo w pomieszczeniach (np. rolnictwo LED, hodowla kontenerowa, akwaponika, hydroponika), rolnictwo na dachach, rolnictwo wspierane przez społeczność oraz ogrody lecznicze, rekreacyjne lub edukacyjne (Prové, Kemper, Loudiyi 2018:18). 
Tak szeroka definicja obejmować może również ogródki działkowe zlokalizowane często - tak jak w Polsce - nawet w dużych miastach ${ }^{1}$. Rolnictwo miejskie oprócz działań wytwórczych może obejmować również dystrybucję żywności, a także hodowlę zwierząt, przede wszystkim niewielkich i tzw. pożytecznych drapieżników oraz pasiecznictwo. Na większą skalę aktywności te prowadzone są najczęściej w obszarach podmiejskich, jednak podejmowane są udane próby ich wprowadzenia $\mathrm{w}$ środowiska silnie zurbanizowane, także w centra dużych miast. W miejscach tych realizowane są uprawy kukurydzy (Baudry 2012: 42), eksperymentalnie również - na przykład na dachu pewnego budynku w Chicago (Beach 2016) - zainicjowano uprawę zboża, co jednak na razie nie przynosi satysfakcjonujących plonów.

Patrząc na zjawisko ogrodnictwa jak na miejski ruch społeczny, kładę nacisk zarówno na oddolny charakter tego ruchu i jego nieformalność, na działania zbiorowe oraz na fakt, że ma on zdolność kulturotwórczą, to znaczy ma potencjał dokonywania zmian. Idee upraw miejskich ucieleśniają się w różnorodnych formach. Przyjmują zarówno postać grządek przy parterowych oknach osiedlowych bloków, uprawę niewielkich ilości warzyw przeznaczonych na własne lub rodzinne potrzeby, jak i przypominające futurystyczne utopie plany pionowego obsadzania roślinnością olbrzymich drapaczy chmur. W swoim tekście skupię się jednak przede wszystkim na dwóch przejawach takiej aktywności, jakimi są tzw. partyzantka ogrodnicza (często uznawana stricte za ogrodnictwo miejskie) i ogrody społeczne, uwzględniając również informacje z Polski. W mojej opinii, choć wydają się one odmienne, można ujmować je jako powiązane ze sobą, niekiedy relacją przyczynowo-skutkową. Wybrane przeze mnie typy ogrodów łączy fakt uprawy ziemi, parcel i działek położonych w mieście, niebędących własnością użytkowników, którzy pracują grupowo i realizują cele pozaekonomiczne. Uzyskany „pożytek” ma być również udziałem większej liczby osób, a płody rolne przekazywane są im całkowicie nieodpłatnie lub tylko za udział w pracach nad ich pozyskaniem, co samo w sobie uznawane jest za wartość.

Miejskie ogrody często są następstwem pozaprawnych, „partyzanckich” działań, których efekty jednak - o ile mają przetrwać - wymagają jakiejś formy legalizacji i społecznego wsparcia.

\section{Ziemia bez ogrodników... ${ }^{2}$}

Współcześni miejscy ogrodnicy decydujący się na podjęcie nielegalnych upraw, często postrzegają miasto jako miejsce niewykorzystanej i porzuconej ziemi.„Porzucenie” nie oznacza braku prawnie określonego właściciela, ale raczej brak oznak aktywności

1 W 2012 roku ogródki działkowe w Krakowie zajmowały około 400 hektarów i zlokalizowane były w kilku dzielnicach. Uprawiało je dwanaście tysięcy działkowców. Nie udało mi się znaleźć bardziej aktualnych danych (Skowrońska 2012).

2 Mówiąc o „ziemi bez ogrodników” i „ogrodnikach bez ziemi” wykorzystuję wypowiedź Richarda Reynoldsa, Mooallem 2008. 
i pozostawienie odłogiem w stanie zaniedbania lub pustki, w oczekiwaniu na wzrost cen lub możliwość korzystnej zabudowy. Richard Reynolds, aktywista i promotor partyzantki ogrodniczej w Wielkiej Brytanii, przekonuje, że istota tych prac polega właśnie na przejęciu i zagospodarowaniu „osieroconej ziemi”. Jego zdaniem, nawet chwilowe przejęcie nad nią pieczy sprawia, że działalność miejskich ogrodników może stać się impulsem korzystnych, prospołecznych zmian i narzędziem edukacji (Reynolds 2006; Hardman 2011:1).

Ideą, którą kierują się zwolennicy wznowienia upraw w środowisku zurbanizowanym jest maksymalne i wydajne wykorzystanie powierzchni ziemi, niemarnowanie jej, przy czym postulowane jest wykorzystywanie prostych narzędzi oraz ekologicznych środków ochrony roślin. Służyć temu ma przywrócenie tradycyjnych technik rolnych, rekultywacji i nawożenia oraz znajomości dawnych gatunków. Wiele takich działań za cel stawia sobie zwrócenie uwagi na kwestie bezpieczeństwa żywnościowego i potrzeby edukacyjne w zakresie zrównoważonego rozwoju (Kamvasinou, Milne, 2019: 176). Dodatkową motywacją dla nich jest również chęć stworzenia dodatkowych i niestandardowych rezerwuarów pożywienia. Miejska produkcja „zdrowego jedzenia” stosująca przyjazne dla ziemi techniki uprawy, z jednej strony miałaby być odpowiedzią na przewidywany kryzys żywnościowy i sposobem na uniezależnienie mieszkańców miast od dostaw pożywienia $z$ zewnątrz, z drugiej - działaniem wpływającym znacząco na ograniczenie emisji spalin, pozostałych zanieczyszczeń związanych z transportem oraz innych śladów ekologicznych. Chociaż można odnaleźć statystyki wskazujące na potencjał rolniczy, jaki ma w sobie miasto ${ }^{3}$, mogące $\mathrm{w}$ opinii wielu zapewnić świeże i zdrowe pożywienie swoim mieszkańcom, pojawiają się także argumenty podkreślające nie tyle możliwości ośrodków miejskich jako producentów żywności, ile ogólny, pozytywny wpływ żywych organizmów wprowadzonych w ich przestrzeń. Wyrażać się on ma, nie tylko w poprawie estetyki, ale też w oczyszczającym powietrze i natleniającym działaniu roślin. Nie mniej istotnym walorem ogrodów miejskich ma być stworzenie miejsca do wypoczynku, rekreacji i wspólnych spotkań mieszkańców. Rośliny (warzywa, kwiaty, a nawet zboża) pojawiają się w mieście nie tylko jako ozdoba, ale i świadomie wprowadzony element mający zwiększyć bioróżnorodność środowiska i równowagę ekosystemu oraz wpłynąć pozytywnie na jego mieszkańców.

Należy jednak podkreślić różnice pomiędzy formami miejskiego ogrodnictwa.

\section{Ogrodnicy bez ziemi...}

Grupy, zorganizowane lub nie, a nawet pojedynczy miejscy ogrodnicy różnią się od siebie celami, sposobem działania, a także podejściem do swoich zajęć, których efekty

3 Z inicjatywy naukowców z Michigan State University, badających możliwości Detroit w zakresie samowystarczalności żywieniowej, przeprowadzono badania, z których wynikało, że do utrzymania swoich mieszkańców miasto potrzebuje 5000 akrów ziemi w intensywnej uprawie, co stanowi tylko 30\% miejskich nieużytków, zob. Colasanti, Litjens, Hamm, 2010. 
mogą planować długo lub krótkoterminowo, co przekłada się na doraźne akcje lub projekty względnie trwałe. W odmienny sposób podchodzą również do kwestii legalności swojej działalności oraz wspólpracy z instytucjami miasta czy innymi właścicielami terenów.

Osobami rozpoczynającymi konkretną działalność ogrodniczą kierują różne powody, a dla wielu obiektem działań niekoniecznie jest dobro lokalnej społeczności, lecz na przykład działania na rzecz praw mniejszości lub opór wobec praktyk władzy. Dla innych jeszcze jest to zabawa lub chęć ekscytującego czy twórczego spędzenia czasu, dla kolejnych - zamierzenie polityczne, chęć zasygnalizowania ważnego problemu społecznego lub rodzaj protestu. Są także tacy, którzy w poczuciu odpowiedzialności za los innych podejmują próby zabezpieczenia możliwości upraw w sytuacji spodziewanego światowego kryzysu żywnościowego (Hardman 2011: 3-4).

Wiele zamierzeń ogrodniczych ma charakter artystyczny (Patman 2015: 276), związane jest ze sztuką ekologiczną mającą uwrażliwić na problemy środowiska miejskiego, co nie oznacza oczywiście, że w ich realizacji nie przewidziano udziału czynnika społecznego - ludzi. W tym kontekście warto wspomnieć o artystycznym eksperymencie „Wheatfield - A Confrontation” Agnes Denes z 1982 roku, nawiązującym tytułem do dzieł Vincenta van Gogha. W ramach tworzenia swego dzieła, dziś uznawanego za profetyczne i niezwykle aktualne (Hoban 2019), obsiała pszenicą pustą, lecz świetnie zlokalizowaną, a przez to drogą działkę na Manhattanie, niedaleko Wall Street i istniejących wówczas wież World Trade Center - symboli światowych rynków finansowych. Większość prac pielęgnacyjnych na dwuakrowym polu wykonywano ręcznie i tradycyjnymi technikami, a w efekcie czteromiesięcznej hodowli zebrano 1000 funtów ziarna ${ }^{4}$. Zdaniem artystki:

Sadzenie i zbieranie pszenicy na ziemi wartej 4,5 miliarda dolarów stworzyło potężny paradoks. Wheatfield był symbolem, uniwersalną koncepcją; reprezentował żywność, energię, handel, handel światowy i ekonomię. Dotyczył niegospodarności, marnotrawstwa, głodu na świecie i troski o środowisko. Zwrócił uwagę na nasze źle ulokowane priorytety5.

Chociaż dzieło Agnes Denes nie było typowym zamierzeniem ogrodniczym (czy rolniczym), lecz wpisywało się w koncepcje sztuki enwironmentalnej, udało jej się zrealizować cele i nagłośnić problemy interesujące i ważne dla dzisiejszych aktywistów.

Projekty z zakresu miejskiego ogrodnictwa ujawniają ekologiczną, środowiskową i społeczną świadomość realizujących je wspólnot i ich zdolność do samoorganizacji. To właśnie one decydują o kształcie ogrodu oraz o harmonogramie działań i rodzaju podejmowanych w nim prac, co jednak w niektórych sytuacjach nie wyklucza udziału

\footnotetext{
4 Agnes Denes, 05.04.2021.

5 Agnes Denes, 05.04.2021.
} 
ekspertów zewnętrznych. Twórcy ogrodów społecznych wskazują na istnienie innych możliwości zagospodarowania miasta niż propozycje instytucjonalne i odgórnie planowane. Zajmowanie kawałków ziemi i uprawianie na nich roślin może być rozpatrywane również jako przejęcie kontroli nad własnym otoczeniem i wzięcie odpowiedzialności za jego wygląd i przeznaczenie. Nie wszystkie tego rodzaju projekty są aktami oporu, wymierzonymi w kulturę „głównego nurtu”. Wiele działań miejskich ogrodników wpisuje się w działania rewitalizujące lub w zamierzenia planistyczne władz miasta, poszczególnych jego dzielnic lub - jak w Polsce - spółdzielni lub wspólnot mieszkaniowych zainteresowanych tanim zagospodarowaniem nieużytków.

\section{Guerrilla Gardening i ogrody społeczne}

Najbardziej radykalnym i zaangażowanym rodzajem miejskiego ogrodnictwa jest partyzantka ogrodnicza (guerrilla gardening).

Działalność ogrodowych partyzantów można zdefiniować lakonicznie jako „nielegalną uprawę cudzej ziemi” (Patman 2015: 275). O specyfice ich pracy decyduje brak zgody właściciela gruntu na jego uprawę, a często działanie na granicy prawa lub nawet jej przekraczanie.

Miejska partyzantka ogrodnicza polega na wyszukiwaniu nieużytków lub zdegradowanego niewielkiego kawałka ziemi należącego do miasta lub prywatnego właściciela, pustych parceli lub miejsc pomiędzy budynkami, a także dachów, uprzątnięciu ich, a następnie zajęciu pod uprawę roślin - kwiatów, warzyw, bylin lub niewielkich krzewów. Nasiona i rośliny pozyskiwane są nieodpłatnie $-\mathrm{z}$ darowizn, $\mathrm{z}$ własnych zbiorów lub przez podział większych egzemplarzy. Jako miejsca sadzenia roślin wykorzystywane są również szpary w murach i ścianach budynków, pasy przy jezdniach, wybetonowane lub wyłożone płytami placyki na osiedlach, na przykład przed garażami, przy śmietnikach lub w okolicach opuszczonych kotłowni. W miejscu takim zakładany jest ogród lub kwietna łąka traktowana jako alternatywa dla trawnika. Niekiedy rośliny zielone lub kwiaty sadzone są do pojemników zrobionych $\mathrm{z}$ wyrzuconych przedmiotów: plastikowych butelek, szuflad, zlewozmywaków, koszy na śmiecie czy nawet porzuconych wraków samochodów. W ten sposób realizując pomysły ogrodnicze, „partyzanci”, dekontekstualizując zwykłe przedmioty, zbliżają się do działań z obszaru sztuki, przyczyniając się do zatarcia granic pomiędzy nią a życiem codziennym.

Dla „partyzantów” wejście na czyją́s parcelę jest działaniem przywracającym i sprawiedliwym. Oznacza ono wprowadzenie na nowo roślinności i życia na leżącą odłogiem ziemię, a zatem przywrócenie jej użyteczności i środowiskowej równowagi. Zawłaszczenie tej ziemi ujmowane jest jako wykorzystywanie przez potrzebujących tego, co nie jest aktualnie przydatne innym, w czym akcje takie przypominają - choć na nieco innym poziomie - squatting, lecz nie budzą aż tak negatywnych emocji (Mooallem 2008).

Większość takich działań jest przyjmowana przez otoczenie społeczne pozytywnie, z życzliwością, a czasem z podziwem, nawet gdy w świetle prawa łączą się 
z wykroczeniem. Jednak są także takie, które z punktu widzenia władz miejskich lub inwestorów powodują znaczne szkody. Przykładem może być częściowe usuwanie płyt chodnikowych, by urządzić w nich klomby, wykorzystywanie do nasadzeń uszkodzeń w asfalcie lub wręcz ich wykuwanie (Barber 2017). Podobnie kontrowersyjne może być wypełnianie ziemią kontenerów na śmieci lub gruz i wypełnianie ich roślinnością, czy umieszczanie pojemników z roślinami na słupach wysokiego napięcia lub dźwigach. Mimo że odbiór tego rodzaju akcji może być różny (także i one wywołują niejednokrotnie uśmiech i zadowolenie oglądających), są klasyfikowane jako wandalizm, a twórcy ze względu na niebezpieczeństwo i konieczność poniesienia dodatkowych kosztów, które spowodowała ich akcja, mogą być ścigani. Sprawia to, że nierzadko działają w nocy i ukrywają swą tożsamość (Adams, Hardman 2014: 1103-1104). Tego rodzaju aktywność $\mathrm{z}$ reguły ma charakter doraźnej interwencji w miejską przestrzeń, a funkcjonowanie „ogrodów” obejmuje zazwyczaj jeden sezon wegetacyjny, a niekiedy trwa znacznie krócej. Nie oznacza to, że brakuje działań ogrodniczych bardziej trwałych i jawnych, dokonywanych na oczach przechodniów (Mooallem 2008).

Początki partyzantki ogrodniczej datowane są na lata 70. XX wieku. Artystka i działaczka społeczna, Liz Christy, wsparła wówczas powstanie grupy aktywistów działających pod nazwą Green Guerillas [!] ${ }^{6}$, która ukwiecała opuszczone domy w śródmieściu Nowego Jorku i specjalizowała się w „produkcji” bomb nasiennych - mieszaniny nasion, ziemi i wody umieszczonych w balonach, prezerwatywach lub szklanych kulach, a potem ich wrzucaniu na opustoszałe działki i pozostawianiu do wykiełkowania. Innym rodzajem działalności było zakładanie wśród nieużytków miejskich eksperymentalnych poletek $\mathrm{z}$ roślinami, które miały ujawnić potencjał upraw prowadzonych $\mathrm{w}$ nieprzyjaznych warunkach wielkiego miasta. Drugim przedsięwzięciem, w które zaangażowała się działaczka w tym czasie było założenie ogrodu na zaniedbanej parceli w dzielnicy Bowery na Manhattanie. Inicjatywa polegała na wspólnej uprawie ziemi, a potem sprawiedliwym korzystaniu z jej plonów przez osoby, które w świetle obowiązujących regulacji nie miały praw własności do tego gruntu. Tę aktywność także określała terminem „guerrilla gardening”. Pomysłodawczyni ruchu, realizując swój pierwszy projekt, z czasem postarała się jednak o uzyskanie stosownych zgód, a za użytkowanie działki wraz $\mathrm{z}$ innymi wolontariuszami wnosiła władzom miejskim opłatę $\mathrm{w}$ wysokości jednego dolara miesięcznie (Palomar 2010: 290-291; Loggins 2007). Przestrzeń ogrodu miała być otwarta, czyli dostępna dla wszystkich, co oznaczało zarówno fizyczny brak ograniczeń, jak i możliwość swobodnego korzystanie z przestrzeni oraz prowadzenia prac nad jej upiększeniem. To miało różnić to przedsięwzięcie od innych miejsc, takich jak parki i publiczne ogrody, w których obowiązywały zakazy i nakazy (np. zakazy wprowadzania psów, siadania na trawnikach, zbierania roślin). Ogród Liz Christy stworzony według tych założeń, a później poszerzony, przetrwał do dziś (jako Liz Christy’s

${ }^{6}$ Green Guerillas, 11.04.2021. 
Bowery-Houston Garden) i został wpisany do amerykańskiego rejestru miejsc historycznych (US National Register of Historic Places). Z czasem zmienił swój charakter ${ }^{7}$, stając się miejscem spotkań i celem wycieczek oraz wprowadzając ograniczenia, tym samym rezygnując z deklarowanej „otwartości”.

O sukcesie tej inicjatywy społecznej, a także następnych ogrodów organizowanych w porozumieniu z władzami miejskimi nie tylko w Stanach Zjednoczonych, zdecydował fakt, że poza zyskami społecznymi i ekologicznymi, zagospodarowanie terenu przy bardzo niskich kosztach zarządzania nieruchomością przyczyniło się do wzrostu atrakcyjności dawniej zaniedbanych miejsc oraz ich ochrony przed niepożądanym użytkowaniem, zaśmiecaniem i dewastacją. A zatem korzyści leżały również po stronie właścicieli gruntów, którzy zachowując swoje prawa, jednocześnie zyskiwali opiekę nad własnością i dodatkowe pożytki. Porozumienie z właścicielami dla ogrodników skutkowało możliwością kontynuowania upraw. Trend ten utrzymuje się nadal, obejmując różne kraje.

Współcześnie tego typu aktywność - tworzenie ogrodów społecznych - przybiera najczęściej formy ogrodów wspólnotowych lub sąsiedzkich. Granica między nimi nie jest ostra, a nazwy te bywają stosowane wymiennie. Jednak ogród sąsiedzki jest uprawiany przez ludzi połączonych miejscem zamieszkania, które stanowi kryterium doboru członków. „Wspólnotowy” łączy z kolei ludzi chcących razem pracować „na ziemi”, lecz niekoniecznie zamieszkujących tę samą przestrzeń. Różnorodność - wiekowa, genderowa, etniczna, rasowa - jest uznawana za dodatkowy walor miejsca i okazję do edukacji $\mathrm{w}$ zakresie tolerancji.

Niezależnie od typu ogrodu, nadrzędną ideą przyświecającą prowadzonym w nich pracom jest stworzenie miejsca „dla wszystkich”, czyli takiego, które uwalnia potencjał ludzkiej energii, przyjaznego dla ludzi i dla zwierząt, przyciągającego ptaki i pożyteczne owady. Miejsce, które stanie się częścią miejskiego ekosystemu, przyczyni się do jego bioróżnorodności (gatunki roślinne i zwierzęce) i nie będzie własnością uprzywilejowanych, lecz stworzy poczucie wspólnoty i odpowiedzialności. Stworzy okazję do wymiany doświadczeń i wiedzy, kreowania wspólnej pamięci i historii, w tym także przekazywania kolejnym pokoleniom wiedzy dotyczącej różnych gatunków roślin, sposobów wytwarzania żywności oraz ich zachowania na przyszłość.

Do aranżacji ogrodowego wnętrza wykorzystuje się wiele materiałów z odzysku oraz surowce wtórne, przede wszystkim materiały naturalne, ale wykorzystywane są także kanistry i większe pojemniki po np. olejach samochodowych, a także rynny. Są to między innymi drewniane skrzynie po warzywach, stare donice, palety, drewniane podkłady kolejowe. Nasadzenia są też robione w workach wypełnionych żyzną ziemią. W ogrodach nie używa się „chemii”: nawozów sztucznych i środków ochrony roślin. Aby przetrwały wymagane jest zaangażowanie lokalnej społeczności, gdy ono ustaje - narażony jest również byt tego rodzaju miejsc.

7 Liz Christy Community Garden, 11.04.2021. 


\section{Ogrodnictwo miejskie w Polsce}

Trudno ustalić początek ogrodnictwa miejskiego w Polsce, można przyjąć jednak, że pojawiło się ono, jak większość ruchów miejskich, po 2004 roku, impulsem do czego była akcesja do Unii Europejskiej, co z jednej strony wywołało przyspieszenie inwestycji w mieście, z drugiej uruchomiło potencjał społeczny (Kubicki 2019:10). W dość skromnej literaturze przedmiotu dotyczącej miejskich ogrodów w Polsce można znaleźć stwierdzenie, że zaczęły się one pojawiać po 2010 roku (Maćkiewicz, Puente-Asuero, Pawlak, 2018: 132). Datę tę można jednak przesunąć o kilka lat wstecz i jako przykład takich działań wskazać zabiegi Jacka Powałki, mieszkańca warszawskich Kabatów, który w 2007 roku doprowadził do obsadzenia drzewami i innymi roślinami zaniedbanego osiedlowego skwerku, na którym powstał „Nasz Park”. Został on założony jako „samowola", a pomysłodawca pierwsze drzewa sadził bez zgody, a nawet przy sprzeciwie urzędów, angażując wyłącznie własne środki. W zamierzeniu wzięli udział mieszkańcy sąsiednich domów, porządkując teren oraz sadząc kolejne drzewa, krzewy i zioła. Dawny nieużytek stał się rekreacyjnym „ogrodem sąsiedzkim”, który z czasem zalegalizowano. Stał się miejscem spotkań, pikników i koncertów (Wojtczuk 2007; Mazuś 2009). W wypowiedziach inicjatora akcji komentującego jej efekty wyraźnie pobrzmiewały tony nawiązujące do idei społeczeństwa świadomego swoich celów, działającego samodzielnie, bez interwencji i inspiracji władz:

(...)z pomocą przeszło 100 sąsiadów budujemy park. Może i nie jest on wielki jak prawdziwe parki, ale wierzę, że budzi on w nas nadzieję na odtworzenie społeczeństwa obywatelskiego. Społeczeństwa, które bierze sprawy w swoje ręce i zmienia otaczającą nas rzeczywistość (Parkowa samowola 2014).

Partycypacja społeczna i mobilizacja mieszkańców wokół określonej przestrzeni mogą doprowadzić zarówno do powstania miejskiego ogrodu, jak i do realizacji innych zamierzeń służących wspólnocie. Aktywność taka może być ruchem mieszkańców wspólpracujących jednak na pewnym etapie z różnymi instytucjami (władzami spółdzielni mieszkaniowej, fundacjami, stowarzyszeniami pozarządowymi, instytucjami kultury takimi jak muzea i teatry) lub z organizacjami miejskimi. Możliwe jest również (od 2011 roku) zgłaszanie i realizacja takich działań w ramach budżetów obywatelskich różnych miast.

W wielu przypadkach ogrodnictwo miejskie wpisuje się w praktyki oporu, choć jak się wydaje - skala działań nie jest tak duża, są mniej radykalne i nie tak spektakularne jak w Europie Zachodniej. Czynne są również grupy „guerrillas” zwane w Polsce Miejską Partyzantką Ogrodniczą lub Zielonymi Partyzantami. Działają w różnych miastach niezależnie i mają rozproszoną strukturę, choć pewną platformą wymiany informacji i koordynacji są media społecznościowe. Wiadomości o wielu ich akcjach nie są jednak upowszechniane, trudno zatem zweryfikować informacje i określić ściśle 
początek tych aktywności w Polsce. Można wskazać na rok 2005, od kiedy swą działalność „"pod szyldem» Miejskiej Partyzantki Ogrodniczej” datuje działający na terenie Śląska architekt krajobrazu Witold Szwedkowski (Witold Szwedkowski: 2020). Polscy „partyzanci” swoje działanie motywują względami ekologicznymi i estetycznymi, a także dążeniem do zrównoważonego rozwoju miasta i rozwojem postaw obywatelskich „Trzeba brać sprawy w swoje ręce. Jeśli mamy być obywatelami, to musimy reprezentować obywatelską postawę i działać, a nie czekać, aż ktoś to za nas zrobi. Sadzenie ma znaczenie" (Opyd 2013).

Interesujące jest to, że niektóre osoby biorące udział w zazielenianiu miasta krytycznie podchodzą do spontanicznych działań partyzanckich, przede wszystkim zasiewania nieużytków za pomocą bomb nasiennych. Wskazują, że łączy się to niejednokrotnie $\mathrm{z}$ nieuwzględnianiem harmonogramu prac porządkowych służb miejskich, co skutkuje niszczeniem wyrosłych roślin (na przykład ścinanych podczas koszenia), wskazują na problemy wynikające $\mathrm{z}$ niekontrolowanego wzrostu i następstw wprowadzenia szkodliwych - potencjalnie - nierodzimych lub inwazyjnych gatunków, wpływających destrukcyjnie na dotychczasowe biośrodowisko (Bomby nasienne: 2019). Jako kontrowersyjne i niepotrzebne uznawane są również akcje sadzenia roślin jadalnych (takich jak na przykład sałata) w dużych i zanieczyszczonych miastach lub w okolicach ruchliwych szos, co sprawia, że są one nieużyteczne dla ludzi i zwierząt. Dodać muszę jednak, że przygana nie wiąże się z wezwaniem do zaniechania takich działań, lecz raczej do namysłu nad wyborem strategii i ich konsekwencjami. W większości przypadków uprawa roślin (jadalnych i ozdobnych), nawet w miejscach w sposób oczywisty „nielegalnych”, spotyka się z przychylnym odbiorem i aprobatą. Pozytywny dyskurs dotyczący działań ogrodniczych, kładący nacisk na ich aktywność i sprawczość, rysuje się również w mediach. Kwestią, która pojawia się przy okazji takich nasadzeń jest kradzież „niczyich" roślin, które z przestrzeni publicznej przenoszone są do prywatnych ogrodów.

W polskich miastach podejmowane są również, choć na małą skalę, zasiewy zbóż. Miało to miejsce na przykład w Gliwicach, choć w tym przypadku nie chodziło raczej o produkowanie żywności (zboże posiano na małej przestrzeni i zbyt późno by spodziewać się plonów), ale o zwrócenie uwagi na problem zieleni i jej braku w mieście (Zasiali zboże: 2017). Polscy działacze ogrodowi włączają się również w światowe inicjatywy mające na celu sygnalizowanie niewystarczającego wykorzystania rolniczych zasobów miasta. Czynnie obchodzą „Międzynarodowy Dzień Partyzanckiego Sadzenia Słoneczników” (1 maja) oraz „Światowy Dzień Siania Dyni w Miejscach Publicznych” (16 maja).

Wiele zamierzeń ogrodniczych w Polsce przybiera formę ogrodów społecznych", rozumianych jako: „teren zagospodarowany ogrodniczo i rekreacyjnie przez lokalną

8 W tej części pracy wykorzystuję swoje obserwacje dotyczące ogrodów społecznych w Krakowie. Wykorzystałam również materiały i zdjęcia oraz informacje umieszczane przez wspólnoty ogrodnicze w mediach społecznościowych. 
społeczność, który wpływa na łączność w miastach ze środowiskiem naturalnym oraz działa w oparciu o zasadę zaufania społecznego" (Szkoła Miejskich Ogrodników 2018). Także i w tym przypadku tworzeniom ogrodów towarzyszą deklaracje o otwartości i możliwości włączenia się do prac kolejnych zainteresowanych osób. Ze względu na rodzaj terenów branych pod uprawę (przestrzeń między budynkami, wewnętrzne place, dachy), w praktyce inicjatywy takie przybierają najczęściej formułę ogrodów sąsiedzkich, a ich istnienie jest uregulowane formalno-prawnie, co obejmuje również zasady użytkowania i członkostwa. Użytkownicy takich ogrodów różnie podchodzą do wspomnianej kwestii „otwartości”, często rozumiejąc ją jako propozycję ograniczoną do konkretnej grupy. „Wspólna uprawa” może być również różnie rozumiana. Oznaczać może rzeczywiste grupowo podejmowane prace lub uprawę wydzielonych grządek na terenie uznawanym za „własność” ogółu. Źródłem środków finansowych dla ogrodów mogą być składki jego użytkowników lub też zbiórki publiczne i granty, co zwykle wymaga także przyjęcia jakiejś prawnej formuły organizacyjnej (stowarzyszenie, fundacja). Ogrody organizowane $\mathrm{w}$ myśl tych zasad powstają $\mathrm{w}$ porozumieniu $\mathrm{z}$ dysponentami gruntów lokalnymi spółdzielniami mieszkaniowymi, władzami miasta czy innymi instytucjami na zasadzie umów dzierżawy lub użyczenia. Muszą również respektować lokalne plany zagospodarowania.

Ogrody mają różne wielkości, mogą to być zaledwie skrawki niegdyś zadeptanego terenu (tzw. mini ogrody), ale też tereny większych rozmiarów. Na przykład Stowarzyszenie Drwinka z Krakowa urządziło ogród o powierzchni pięciu arów, a ponadto agituje na rzecz większego projektu, utworzenia Parku Rzecznego między osiedlami Kozłówek i Piaski. Stowarzyszenie ochroniło przed zabudową dziesięcioarową działkę miejską i wywalczyło powstanie na niej ogrodu sensorycznego „Synestezja” (przy ulicy Adama Bochenka), sfinansowanego ze środków publicznych i ocenianego jako przykład udanej współpracy instytucji i społeczności lokalnej (Kajdański 2017).

Wiele projektów ogrodowych realizowanych $\mathrm{w}$ przestrzeni miasta pomyślanych jest jako przedsięwzięcia czasowe, zaplanowane tylko na kilka lat lub - jak ogrody przy dawnej Fabryce Norblina w Warszawie - na jeden sezon. W ich przypadku nie chodzi o stworzenie trwałych założeń ogrodowych, ale o akcje uświadamiające, edukacyjne i zachęcające do naśladownictwa już na własny rachunek. Znane są również przypadki, gdy zakładano ogrody, które początkowo gromadziły liczną grupę zainteresowanych, a potem, pozostawione same sobie, niszczały. Przykładem może być ogród działający przy Teatrze Współczesnym w Warszawie.

Niezależnie od przyjętej formuły działania, deklarowanym celem ogrodów społecznych ma być „ożywienie” miasta. Jest ono ujmowane szeroko. Oznacza nie tylko wprowadzenie zieleni i mikroorganizmów, ale również odnowę wspólnoty, zmniejszenie anonimowości osób mieszkających w blokowiskach, poprawę bezpieczeństwa, zbliżenie generacji starszych i młodszych oraz wykreowanie grupy sąsiedzkiej złożonej z ludzi połączonych prawdziwymi i głębokimi więzami społecznymi. 


\section{Czyje jest miasto?}

Zjawisko miejskiego ogrodnictwa często jest intepretowane jako działanie polityczne, w tym sensie, że dotyczy relacji między dominującymi i podporządkowanymi. Ci pierwsi mają nie tylko władzę, lecz również zasoby oraz biurokratyczną sprawczość. Sprzeciw może mieć charakter rozproszony, niebezpośredni i wyrażać się w wielu formach (Ortner 2015), niekoniecznie przybierając wyraz „tradycyjnych” działań zmierzających do zdobycia lub utrzymania władzy, co rzecz jasna, nie wyklucza takich starań (Erbel 2014). Podporządkowani mogą „wziąć sprawy w swoje ręce”, a przez chociażby realizacje projektów ogrodowych krytykować władze i wskazywać na ich uchybienia. Oznacza to kwestionowanie (świadome lub nie) gentryfikacji, neoliberalnej polityki w zakresie budownictwa wielomieszkaniowego i poczynań deweloperów, które prowadzą do fragmentacji miejskiej przestrzeni oraz jej prywatyzacji. Zmiany te zachodzące kosztem słabszych (mniej zamożnych i wpływowych) mieszkańców oceniane są jako niekorzystne i wykluczające, a zatem przeciwstawianie się im poprzez prowadzenie niezależnych prac ogrodniczych przywracających, choć częściowo, równowagę, jest traktowane jako forma krytyki i oporu (Baudry 2012: 35). Reakcja może przyjmować formę jawnego lub ukrytego kwestionowania sposobów zarządzania miastem i zagospodarowywania miejsc publicznych. Może wyrażać się chęcią wyręczenia władz w obszarach, które te - zdaniem mieszkańców - zaniedbały lub w których oficjalne działania nie przynoszą zadawalających rezultatów. Łączą się z żądaniami przywrócenia „prawa do miasta" (Harvey 2013; Adams, Hardman 2014: 1106), to znaczy odzyskania chociaż częściowej decyzyjności i kontroli nad zamieszkiwaną przestrzenią oraz możliwości wpływania na jej kształt. W tym miejscu pojawiają się więc społeczne inicjatywy stworzenia miejskich ogrodów i parków.

Interpretacja miejskiego ruchu ogrodniczego jako infrapolityki jest trafna, lecz powinna uwzględniać również działania drugiej strony. Wiele $z$ nich, podejmowanych przez władze miasta czy, szerzej, właścicieli gruntów jako reakcja na obywatelskie zagospodarowywanie przestrzeni, przypomina zjawisko, które John Fiske nazwał inkorporacją, oznaczającą proces przejęcia znaków protestu i oporu, w wyniku czego „obracają się na korzyść osób, instytucji, czy zjawisk, którym się sprzeciwiają” (Fiske 2010: 19). Termin ten odnoszę przede wszystkim do usiłowań różnych instytucji chcących ukierunkować i kontrolować oddolne aktywności ogrodnicze i włączyć je w swoje programy i strategie działań. Warto zauważyć, że niektóre ogrody społeczne funkcjonujące w Polsce powstały jako rezultat działań odgórnych (Maćkiewicz, Puente-Asuero, Pawlak 2018: 148), co potwierdza tezę o przejmowaniu działań wyrażających sprzeciw oraz ich „naturalizacji”. Wymownym przykładem innej kategorii praktyk inkorporujących `mogą być również bomby nasienne - militaryzujący symbol zielonych partyzantów, ich „wizytówka” i jednocześnie narzędzie pracy. Dzisiaj są one produkowane przez przedsiębiorstwa hodowlano-nasienne, sprzedawane przez sklepy i supermarkety jako „gadżet” dla „fanów ekologii" lub zabawka edukacyjna dla dzieci. Tym samym tracą wymowę narzędzia 
radykalnych aktów społecznych, stając się jednym $\mathrm{z}$ wielu neutralnych $\mathrm{w}$ wymowie towarów i akcesoriów ogrodniczych.

\section{Zakończenie}

W XXI wieku władze wielu miast stanęły w obliczu zmian w sposobie wartościowania miejskiej przestrzeni, co wiąże się ze zmianę trendów w metodzie oceny „pustych” (niezagospodarowanych infrastrukturalnie) miejsc w miastach, które do niedawna rozpatrywane były w kategoriach niepowodzenia modernizacji, zaniedbań i marnotrawstwa przestrzeni (Kamvasinou, Milne, 2019: 153). Aktualnie tendencja odwróciła się, pożądane jest zazielenianie miast i tworzenia w nich miejsc przyjaznych dla mieszkańców i ich rozwoju, co zresztą koresponduje ze zgłaszanymi przez nich postulatami. Władze municypalne są zainteresowane niskobudżetowym zagospodarowaniem terenów pozostających pod ich kontrolą, zwłaszcza nieatrakcyjnie zlokalizowanych lub nieprzedstawiających wartości dla przedsiębiorców budowlanych. Organy miejskie opracowują systemy zachęt mających motywować właścicieli działek i entuzjastów miejskiego ogrodnictwa do współpracy. W San Francisco oferują prywatnym właścicielom niezabudowanych nieruchomości znaczące ulgi podatkowe, jeżeli zgodzą się przekazać swoje działki na potrzeby projektów związanych z miejskim ogrodnictwem na pięć lat lub na dłużej (Buren 2016). Zarząd Zieleni Miejskiej w Krakowie realizuje wiele projektów z zakresu miejskiego ogrodnictwa i urban agriculture, wspólpracując w tym zakresie $\mathrm{z}$ instytucjami Unii, proponując grupom co najmniej trzyosobowym zawarcie umowy oraz zapewniając im pomoc, szkolenia i wsparcie, a także nasiona i sadzonki roślin. Organizowano ponadto cykliczne warsztaty ogrodnicze o charakterze praktycznym Szkołę Miejskich Ogrodników. Podobną działalność prowadzi również Zarząd Zieleni stołecznego miasta Warszawa. W innych, nie tylko polskich, miastach zachęca się mieszkańców i właścicieli posesji do aktywności, wskazując, że zagospodarowana działka zyska na estetyce, nie tylko upiększy okolicę, ale również zyska na wartości. Towarzyszą temu hasła edukacyjne i socjalizacyjne, skłaniające do podjęcia działań wspólnotowych i pracy na rzecz przestrzeni miejskiej ukazywanej jako konkretne społeczne dobro. Oczywiście, działania takie w wielu aspektach pokrywają się z oczekiwaniami mieszkańców, nie sposób jednak nie odnieść wrażenia, że jest to - jak również „wspólnotowa” retoryka - próba wyprzedzenia i skanalizowania bardziej wyraźnych oznak niezadowolenia i stanowczych prób odzyskania miasta.

$\mathrm{Z}$ drugiej strony jednak, zaangażowanie instytucji $\mathrm{w}$ promowanie miejskiego ogrodnictwa można ocenić jako sukces wizji miasta i wartości wykreowanych przez aktywistów tego ruchu, który może być czynnikiem zmian kulturowych. Jak zauważyła Sherry Ortner: „Polityka zewnętrznej dominacji oraz wewnętrzna polityka subordynowanej grupy mogą bowiem współgrać lub odpierać się nawzajem; kultury dominujących i podporządkowanych mogą skutecznie przemawiać do siebie nawet wtedy, gdy mówią przeciw sobie” (Ortner 2015:177). Zmiana stosunku do miasta, „oswajanie”, rezygnacja 
z jego wyobrażeń jako miejsca „cywilizacji”: przemysłu, pośpiesznego ruchu i anonimowości, a także zacieranie dychotomii wieś - miasto są również efektem tych przemian.

Różne przejawy miejskiego ogrodnictwa rozpatrywać można zatem jako sytuacje dwustronnego dostosowania, relacyjne i wpływające na stan względnej równowagi między siłami rywalizującymi o miasto, lecz również zainteresowanymi jego rewitalizacją.

\section{Bibliografia}

Adams D., Hardman M. 2014. Observing Guerrillas in the Wild: Reinterpreting Practices of Urban Guerrilla Gardening, Urban Studies, No. 6 (May), 1103-1119.

Barber A. 2017. Guerrilla gardeners warned to stop filling in Bath's potholes with flowers by council officials, 15.05. https://www.bathchronicle.co.uk/news/bath-news/guerrilla-gardeners-warned-stop-filling-60095, 14.04.2021.

Baudry S. 2012. Reclaiming Urban Space as Resistance, Revue Française d'Études Américaines, No.131,Infrapolitics and mobilizations/Infrapolitique et mobilisations (ler Trimestre),32-48.

Beach G. 2016. Rooftop wheat fields elevate Chicago's urban farming scene to exciting new heights, 27.09, https://inhabitat.com/rooftop-wheat-fields-elevate-chicagos-urban-farming-scene-to-exciting-new-heights/, 08.04.2021.

Bomby nasienne oraz ogrodnictwo partyzanckie, 2019, https://dzicyzapylacze.p1/bomby-nasienne -oraz-ogrodnictwo-partyzanckie/, 14.04.2021.

Buren D. van. 2016. Can Cities Feed Themselves? A Look at Urban Farming in 5 Major American Urban Centers, 09.03., http://yardfarmers.us/can-cities-feed-themselves-a-look-at-urbanfarming-in-5-major-american-urban-centers/, 30.11.2018.

Certomà C., 2015. Critical Urban Gardening. RCC Perspectives, No. 1, Think Global, Eat Local: Exploring Foodways, 13-18.

Colasanti K., Litjens Ch., Hamm M. 2020. Growing Food in the City: The Production Potential of Detroit's Vacant Land, https://www.canr.msu.edu/foodsystems/uploads/files/Growing Food_in_the_City_-_Colasanti_Litjens_Hamm.pdf, 30.11.2018.

Erbel J. 2014. Ruchy miejskie jako nowa forma zaangażowania społecznego. Wtadza Sadzenia, nr 4, 37-47.

Fiske J.2010.Zrozumiec kulturępopularna, przeł.K. Sawicka, Kraków:Wydawncitwo Uniwersytetu Jagiellońskiego.

Flores H. C. 2006. Food Not Lawns: How to Turn Your Yard Into a Garden and Your Neighborbood into a Community, Chelsea Green Publishing.

Hardman M.2011. Understanding guerrilla gardening: an exploration of illegal cultivation in the UK, Working Paper, no. 1, Centre for Environment and Society Research, Birmingham.

Harvey D. 2013. The Right to the City, 04.10, https://davidharvey.org/media/righttothecity.pdf, 14.03.2021.

Hoban P. 2019. Agnes Denes's Prophetic Wheatfield Remains As Relevant As Ever, [online] https:// www.architecturaldigest.com/story/agnes-denes-prophetic-wheatfield-remains-as-relevant-as-ever, [dostęp: 10.04.2021]. 
Kajdański J.2017. Synestezja przy ul. Bochenka, Wiadomości, 10.07. http://wiadomoscipodgorze. p1/synestezja-przy-ul-bochenka/, 29.11.2018.

Kamvasinou K., Milne S. A. 2019. Surveying the creative use of vacant space in London, c. 1945-95, [W:] Empty Spaces. Perspectives on Emptiness in Modern History, C. J. Campbell, A. Giovine, J. Keating (eds.), University of London Press; Institute of Historical Research, 151-178.

Kubicki P. 2019. Ruchy miejskie w Polsce. Dekada doświadczeń, Studia Socjologiczne nr 3 (234), 5-30.

Loggins D., 2007. Houston between Bowery \& Second Avenue. http://www.lizchristygarden.us/, 15.07.2020.

Maćkiewicz B., Puente-Asuero R., Pawlak K. 2018. Reclaiming urban space: a study of community gardens in Poznań, Quaestiones Geographicae, 37, 131-150.

Mazuś M. 2009. Sąsiadki rządzą w parku na Kabatach, Gazeta Wyborcza. Gazeta w Warszawie, 22.06. https://warszawa.wyborcza.pl/warszawa/1,95190,6741881,Sasiadki_rzadza_w_parku_na_Kabatach.html, 14.04.2021.

Mooallem J. 2008. Guerrilla Gardening, The New York Times Magazine, 08.06, https://www.nytimes.com/2008/06/08/magazine/08guerrilla-t.html, 11.04.2021.

Obordo R. 2018. Fresh, free and beautiful': the rise of urban gardening, The Guardian, 07.06 https://www.theguardian.com/world/2018/jun/07/fresh-free-and-beautiful-the-rise-ofurban-gardening, 14.04.2021.

Opyd J. 2013. Miejska Partyzantka Ogrodnicza w Katowicach sadzi rośliny nocą, Dziennik Zachodni, 24.06., https://dziennikzachodni.pl/miejska-partyzantka-ogrodnicza-w-katowicach-sadzi-rosliny-noca-zdjecia/ar/928693, 15.04.2021.

Ortner S. 2015. Opór i problem etnograficznej odmowy, przeł. A. Pasieka, [W:] Opór i dominacja. Antologia tekstórw, A. Pasieka, K. Zielińska (red.), Kraków, 159-180.

Palomar C.2010.From the Ground Up:Why Urban Ecological Restoration Needs Environmental Justice, Nature and Culture, No. 3, Special Symposium on Urban Ecological Restoration (Winter), 290-291.

Parkowa samorwola.2014.07.08.,http://synchronicity.beczmiana.pl/parkowa-samowola/,14.04.2021. Patman S. 2015. A New Direction in Garden History, Garden History, 43, No. 2, 273-283.

Prové Ch., Kemper D., Loudiyi S. 2018. The Modus Operandi of Urban Agriculture Initiatives, Nature and Culture, No. 1, Civil Society and Urban Agriculture in Europe, 17-46.

Reynolds R. 2006. Gardeners without borders, The Guardian, 20.04., https://www.theguardian. $\mathrm{com} / \mathrm{news} / \mathrm{blog} / 2006 / \mathrm{apr} / 20 /$ guerrillagarde, 06.04.2021.

Skowrońska M. 2012. Ogródki działkowe znikną, zamiast nich wyrosną bloki?, Gazeta Wyborcza. Gazeta w Krakowie, 30.06. https://krakow.wyborcza.pl/krakow/1,44425,12043706, Ogrodki_dzialkowe_znikna_zamiast_nich_wyrosna_bloki_html, 14.04.2021.

Szkota Miejskich Ogrodników - projektowanie ogrodu spotecznego, 2018, https://zzm.krakow.pl/ aktualnosci/500-szkola-miejskich-ogrodnikow-projektowanie-ogrodu-spolecznego.html, 14.04.2021.

Szwedkowski Witold. 2020. 21.09., https://sak.org.pl/szwedkowski-witold/, 17.04.2021. 
Wojtczuk M. 2007. Kabaty - powstaje nielegalny park, Gazeta Wyborcza. Gazeta w Warszawie, 08.06., https://warszawa.wyborcza.pl/warszawa/1,54420,4212717.html, 14.04.2021.

Zasiali zboże nad tunelem DTŚ. "Chcemy zwrócić uwage na zieleń w mieście". Co na to urzędnicy?. 2017. https://www.24gliwice.pl/wiadomosci/zasiali-zboze-nad-tunelem-dts-chcemy -zwrocic-uwage-na-zielen-w-miescie-co-na-to-urzednicy/, 14.04.2021.

\section{Źródła internetowe}

Agnes Denes : http://www.agnesdenesstudio.com/works7.html, 05.04.2021.

Green Guerillas : https://www.greenguerillas.org/, 11.04.2021

Liz Christy Community Garden: http://www.lizchristygarden.us/, 11.04.2021.

Autorka:

Dr Renata Hołda

e-mail: renata.holda@uj.edu.pl 